\title{
Antibacterial activity of nineteen selected natural products against multi-drug resistant Gram-negative phenotypes
}

\author{
Armelle T. Mbaveng ${ }^{*}$, Louis P. Sandjo², Simplice B. Tankeo ${ }^{1}$, Ache R. Ndifor ${ }^{3}$, Ambassa Pantaleon², \\ Bonaventure T. Nagdjui ${ }^{3}$ and Victor Kuete ${ }^{1,4^{*}}$
}

\begin{abstract}
The present study was designed to assess the antimicrobial activity of 19 natural products belonging to terpenoids, alkaloids, thiophenes and phenolics against a panel of 14 Gram-negative multidrug-resistant (MDR) bacteria. The results demonstrated that amongst the studied compounds, alkaloids and terpenoids were less active contrary to flavonoids: neocyclomorusin (3) and candidone (6) and isoflavonoids: neobavaisoflavone (8) and daidzein (12). Thiophene, 2-(penta-1,3-diynyl)-5-(3,4-dihydroxybut-1-ynyl)thiophene (17) showed moderate and selective activities. Compounds $\mathbf{3 , 6 , 8}$ and $\mathbf{1 2}$ displayed minimal inhibitory concentration (MIC) ranged from 4 to $256 \mathrm{\mu g} / \mathrm{mL}$ on all the 14 tested bacteria. MIC values below $10 \mu \mathrm{g} / \mathrm{mL}$ were obtained with $\mathbf{8 , 3}, \mathbf{6}$ and $\mathbf{1 2}$ against $50,42.9,35.7$ and $21.4 \%$ of the tested bacteria. The lowest MIC value of $4 \mu \mathrm{g} / \mathrm{mL}$ was obtained with compound $\mathbf{3}$ against Klebsiella pneumoniae ATCC11296, Enterobacter cloacae BM47, compound $\mathbf{6}$ against Escherichia coli ATCC8739, K. pneumoniae ATCC11296, E. cloacae BM47 and compound 8 against K. pneumoniae ATCC11296 and E. cloacae BM47. The activity of flavonoid $\mathbf{3}$ was better or equal to that of chloramphenicol in all tested K. pneumoniae, Providencia stuartii, E. aerogenes, E. cloacae and Pseudomonas aeruginosa strains. Within isoflavonoids, neobavaisoflavone scaffold was detected as a pharmacophoric moiety. This study indicates that natural products such as $\mathbf{3 , 6}$ and $\mathbf{8}$ could be explored more to develop antimicrobial drugs to fight MDR bacterial infections.
\end{abstract}

Keywords: Antibacterial, Flavonoids, Isoflavonoids, Natural products, Multidrug resistance

\section{Background}

Infectious diseases including bacterial infections continue to be a serious health problem worldwide. Multidrug-resistant (MDR) pathogens considerably increase the mortality and morbidity. In effect, clinically, the continuous emergence of Gram-negative MDR bacteria drastically reduced the efficacy of antibiotic arsenal leading globally to an increase of the frequency of therapeutic failure (Rice 2006). Consequently, new antibacterials are needed to fight these bacterial pathogens, but progress in developing them have been slow (Fischbach and Walsh 2009). Plant

\footnotetext{
*Correspondence: armkuete@yahoo.fr; kuetevictor@yahoo.fr 1 Department of Biochemistry, Faculty of Science, University of Dschang, P.O. Box 67, Dschang, Cameroon

${ }^{4}$ P.O. Box 1499, Bafoussam, Cameroon

Full list of author information is available at the end of the article
}

kingdom represents an enormous source of new chemotherapeutic agents to tackle microbial infections. Several natural compounds belonging to the usual pharmaceutical library have been tested for their ability to combat resistant bacteria (Fischbach and Walsh 2009; Saleem et al. 2010). More than 450 natural metabolites with antimicrobial activity have been reported in the period 2000-2010 (Saleem et al. 2010). Some of the best plant metabolites from African medicinal plants with antibacterial activity against MDR Gram-negative phenotypes include laurentixanthone $\mathrm{B}$ (xanthone), diospyrone and plumbagin (naphthoquinone), isobavachalcone and 4-hydroxylonchocarpin (flavonoids) and MAB3 (coumarin) (Kuete et al. 2010, 2011a). The rationale of this work comes to the fact that secondary metabolites belonging to terpenoids, phenolics and alkaloids previously displayed prominent antibacterial activity against MDR Gram-negative bacteria

\section{望 Springer}


expressing active efflux pumps (Kuete et al. 2010, 2011a). Therefore, the present study was designed to determine the antibacterial activity of several molecules, including terpenoids, alkaloids, thiophenes and phenolics, against different bacterial strains expressing MDR phenotypes. Furthermore, we highlighted the possible pharmacophoric cores amongst the active compounds.

\section{Results}

\section{Studied compounds}

Compounds tested in the present study (Fig. 1) were previously or newly isolated from several Cameroonian plants. They include atalantoflavone (1; yellow solid; m.p. 286.2-287.7 ${ }^{\circ} \mathrm{C}$ ) (Ouete et al. 2013); $2^{\prime}$-hydroxyatalantoflavone (2; reddish gum) (Ouete et al. 2013); neocyclomorusin (3; yellow solid, m.p. $263.2-266.7^{\circ} \mathrm{C}$ ) (Ouete et al. 2013; Cho et al. 2011); 2-(3,5-dihydroxyphenyl)benzofuran-5,6-diol (4; yellow oil) (Ouete et al. 2014; Noguchi et al. 1994); 4-hydroxy-2,6-di-(3',4'dimethoxyphenyl)-3,7-dioxabicyclo-(3.3.0)octane (5; yellow solid; m.p. $168.5-169.9^{\circ} \mathrm{C}$ ) (Kuete et al. 2013); candidone (6; yellowish powder; m.p. $95.1-96.2{ }^{\circ} \mathrm{C}$ ) (Ouete et al. 2013; Kuete et al. 2013); isoneorautenol (7; yellowish solid; m.p. 156.2-157.8 ${ }^{\circ} \mathrm{C}$ ) (Nkengfack et al. 1995; Kuete et al. 2014); neobavaisoflavone (8; yellowish oil) (Nkengfack et al. 1994; Kuete et al. 2014); tecleaverdoornine (9; amorphous solid) (Ayafor and Okogun 1982; Sandjo et al. 2014); maculine (10; amorphous solid) (Nunes et al. 2005; Kuete et al. 2008b; Sandjo et al. 2014); deacetylnomilin (11; colorless oil) (Bennett and Hasegawa 1981); daidzein (12; yellowish gum) (Basha et al. 2013); isowighteone (13; yellowish gum) (Wang et al. 2001); dorstenin (14; white solid; m.p. $136-139^{\circ} \mathrm{C}$ ) (Kuster et al. 1994; Abegaz et al. 2004); herranone (15; colorless solid; m.p. 285-287 ${ }^{\circ} \mathrm{C}$ ) (Wiedemann et al. 1999); isogarcinol (16; brown oil) (Marti et al. 2010); 2-(penta-1,3-diynyl)-5(3,4-dihydroxybut-1-ynyl)thiophene (17; brownish oil) (Shi et al. 2010); ulmoside A (18; brown oil) (Rawat et al. 2009) and 3,4,3'-tri-O-methylellagic acid (19; brown solid; m.p. $282-284{ }^{\circ} \mathrm{C}$ ) (Gao et al. 2014). These compounds belong to flavonoids $(\mathbf{1 - 3}, \mathbf{6}, \mathbf{1 8})$, isoflavonoids $(7,8,12,13)$, benzophenone (16), benzofuran (4), ellagic acid derivative (19), lignan (5), alkaloids $(9, \mathbf{1 0})$, terpenoids $(\mathbf{1 1}, \mathbf{1 5})$ and thiophene $(\mathbf{1 9})$. They were tested for their antimicrobial activity on a panel of 14 bacterial strains and the results are summarized in Table 1.

\section{Activity of terpenoids}

Both diterpenoid (11) and triterpenoid (15) exhibited very weak activities. Deacetylnomilin (11) and herranone (15) had detectable MIC values against 2/14 (14.3 \%) and 5/14 (35.7 \%) bacterial strains respectively (Table 1$)$. However, no minimal bactericidal concentration (MBC) value was obtained with the two terpenoids.

\section{Activity of alkaloids}

Furoquinoline alkaloids tecleaverdoornine (9) and maculine (10) displayed low activity against the tested bacteria. Their inhibitory effects were observed on $1 / 14$ (7.1\%) and 2/14 (14.3\%) microbial strains, respectively, for 9 and 10 (Table 1).

\section{Activity of thiophene}

The compound 2-(penta-1,3-diynyl)-5-(3,4-dihydroxybut-1-ynyl)thiophene (17) showed MIC values below $100 \mu \mathrm{g} / \mathrm{mL}$ against Escherichia coli ATCC 8739, Enterobacter aerogenes ATCC 13048 and EA27, Klebsiella pneumoniae ATCC11296 and Providencia stuartii ATCC29916 (Table 1).

\section{Activity of phenolics (flavonoids, isoflavonoids, benzophenone, benzofuran, coumarins, ellagic acid derrivative and lignan)}

The best activities were obtained with phenolic compounds; amongst them, flavonoids neocyclomorusin (3) and candidone (6) as well as isoflavonoids neobavaisoflavone (8) and daidzein (12) had MIC values ranged from 4 to $256 \mu \mathrm{g} / \mathrm{mL}$ on all the 14 tested bacteria. Moreover, MIC values below $10 \mu \mathrm{g} / \mathrm{mL}$ were obtained with $\mathbf{8 , 3}, \mathbf{6}$ and $\mathbf{1 2}$ against 7/14 (50\%), 6/14 (42.9\%), 5/14 (35.7\%) and 3/14 $(21.4 \%)$ tested bacteria respectively. MIC values below $100 \mu \mathrm{g} / \mathrm{mL}$ were obtained with compound 3 on all tested bacteria. MBC values below $10 \mu \mathrm{g} / \mathrm{mL}$ were also obtained with compound 3 against K. pneumoniae ATCC11296 and Enterobacter cloacae BM47 whilst values ranged from 8 to $256 \mu \mathrm{g} / \mathrm{mL}$ were noted on all tested pathogens. The lowest MIC value of $4 \mu \mathrm{g} / \mathrm{mL}$ was obtained with compound 3 against $K$. pneumoniae ATCC11296, E. cloacae BM47, compound 6 against E. coli ATCC8739, K. pneumoniae ATCC11296, E. cloacae BM47 and compound 8 against K. pneumoniae ATCC11296 and E. cloacae BM47.

\section{Structure-activity relationship study}

When analyzing the structure-activity relationship, it can be observed that terpenoids (both diterpenoids and triterpenoids) as well as the tested furoquinoline alkaloids were poor antimicrobial compounds. A keen look of the activities of phenolics shows that benzophenone (16) were not active meanwhile coumarin (14), lignan (5) and benzofuran (4) were also found to be poor antibacterial agents. The best activities were obtained with flavonoids and isoflavonoids. Within flavonoids, it appeared that hydroxylation of compound $\mathbf{1}$ to yield $\mathbf{2}$ did not significantly changed the antibacterial activity (Table 1 ). 
<smiles>CC1(C)C=Cc2c(cc(O)c3c(=O)cc(-c4ccc(O)cc4)oc23)O1</smiles>

1<smiles>Oc1cc(O)cc(-c2cc3cc(O)c(O)cc3o2)c1</smiles>

4<smiles>CC1(C)C=Cc2c(cc(O)c3c(=O)cc(-c4ccc(O)cc4O)oc23)O1</smiles>

2<smiles>COc1ccc(C2OC(O)C3C(c4ccc(OC)c(OC)c4)OCC23)cc1OC</smiles>

5<smiles>CC1(C)C=Cc2c(cc(O)c3c(=O)c4c(oc23)-c2ccc(O)cc2OC(C(C)(C)O)C4)O1</smiles><smiles>COc1cc(OC)c2c(c1CC=C(C)C)OC(c1ccccc1)CC2=O</smiles><smiles>CC1(C)C=Cc2cc3c(cc2O1)OC1c2ccc(O)cc2OCC31</smiles>

7<smiles>c1ccoc1</smiles>

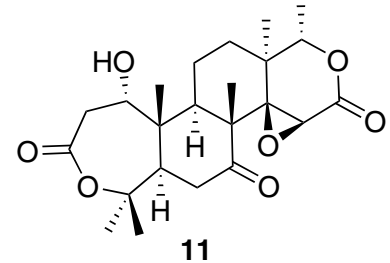<smiles>O=c1c(-c2ccc(O)cc2)coc2cc(O)cc(O)c12</smiles>

12<smiles>CC(CCOc1c2ccoc2cc2oc(=O)ccc12)C1=CC(=O)C(C)(C)O1</smiles>

14

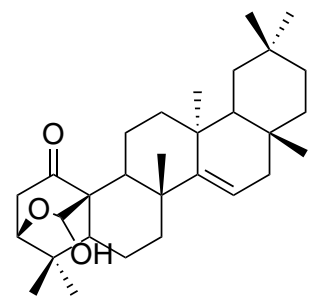

15<smiles>COc1c2cc3c(cc2nc2occc12)OCO3</smiles>

10<smiles>CC1(C)C=Cc2cc(-c3coc4cc(O)cc(O)c4c3=O)ccc2O1</smiles>

13<smiles>CC(C)=CCOC1C(C)(C)C(=O)C(CC=C(C)C)=C2OC(C)(C)C(CC=C(C)C)CC21CC=C(C)C</smiles>

16<smiles></smiles>

19

Fig. 1 Chemical structures of tested compounds. Atalantoflavone (1); 2'-hydroxyatalantoflavone (2); neocyclomorusin (3); 2-(3,5-dihydroxyphenyl) benzofuran-5,6-diol (4); 4-hydroxy-2,6-di-(3',4'-dimethoxyphenyl)-3,7-dioxabicyclo-(3.3.0)octane (5); Candidone (6); isoneorautenol (7); neobavaisoflavone (8); tecleaverdoornine (9); maculine (10); deacetylnomilin (11); daidzein (12); isowighteone (13); dorstenin (14); herranone (15); 2-(penta1,3-diynyl)-5-(3,4-dihydroxybut-1-ynyl)thiophene (17); isogarcinol (16); ulmoside A (18) and 3,4,3'-tri-O-methylellagic acid (19) 


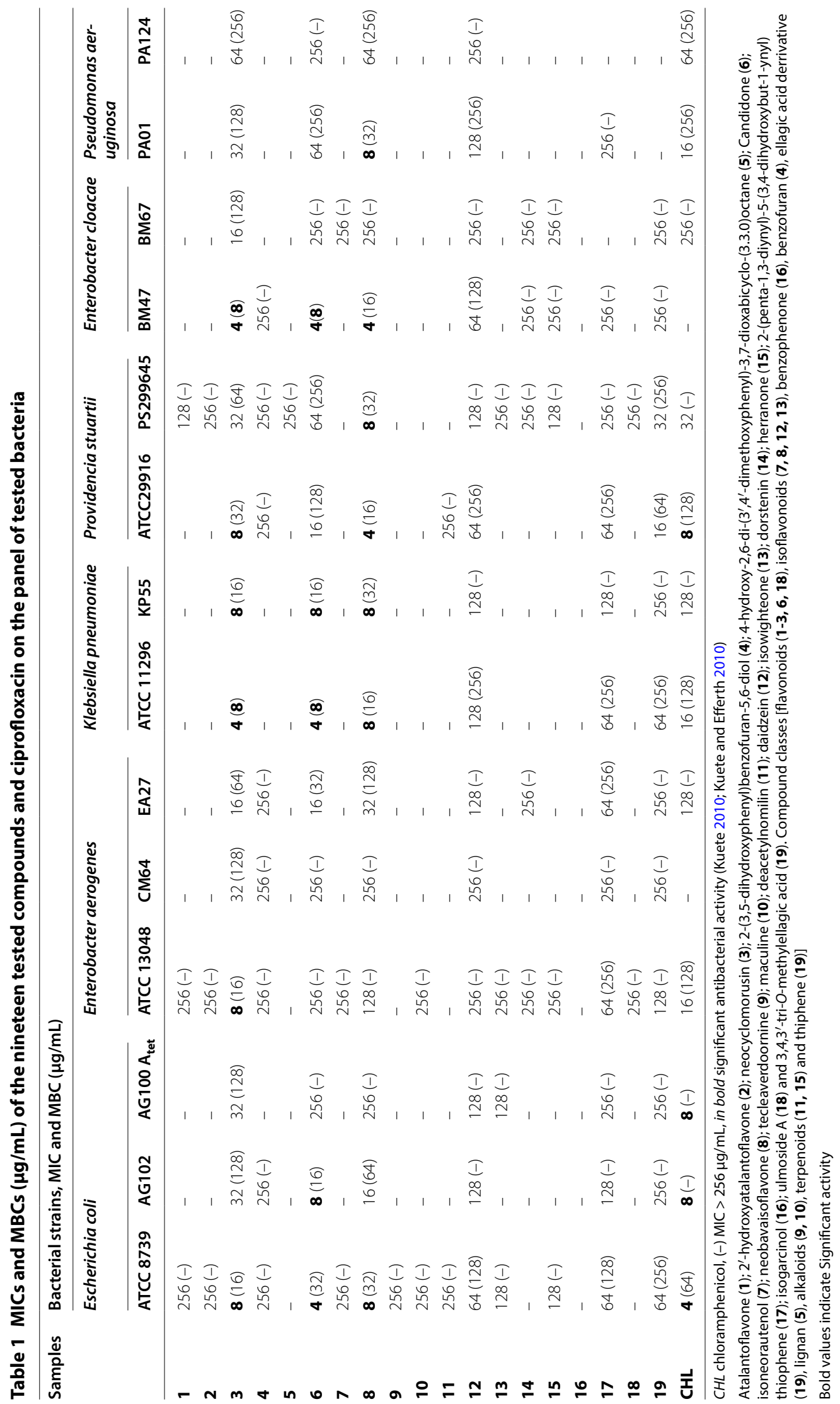


The presence of a cyclic prenyl moiety in the heterocyclic portion of flavone $\mathbf{3}$ improves significantly the activity and provides a large antimicrobial selectivity. Regardless the presence of the $\alpha, \beta$-unsaturated double bond, compound $\mathbf{6}$ showed interesting activity like 3. Compound 6 differs from 1 to 3 with the $\alpha, \beta$-unsaturated double bond and its high lipophilicity turning this latter along with $\mathbf{3}$ as two pharmacophores to be explored for antimicrobial chemotherapy. Nevertheless, the high hydrophilicity of compound 18 reduced drastically its antimicrobial potency (Fig. 2). Concerning the activity of isoflavonoid, it also appeared that neobavaisoflavone (8) was another pharmacophoric moiety (Fig. 3). Any modification of the structure of compound $\mathbf{8}$ such as cyclisation or absence of prenyl group resulted in the reduction of antibacterial activity as it can be seen with compounds 7, 12 and 13 .

\section{Discussion}

Bacterial multidrug resistance represents a major hurdle in the treatment of infectious diseases. In the present study, we tested a panel of bacterial strains including both reference ATCC strains and MDR phenotypes expressing active efflux pumps (Kuete et al. 2010, 2011a; Fankam et al. 2011). In fact, tripartite drug efflux pumps, mainly those clinically reported as AcrAB-TolC in Enterobacteriaceae or as MexAB-OprM in Pseudomonas aeruginosa tested in the present study, play a key role in multidrug resistance of pathogenic
Gram-negative bacteria (Nikaido 2009; Davin-Regli et al. 2008). Interestingly, a MIC value of $64 \mu \mathrm{g} / \mathrm{mL}$ was recorded with the best compounds (namely flavonoid $\mathbf{3}$ and isoflavonoid 8) against the problematic MDR strain P. aeruginosa PA124. This value was identical to that of the reference compound chloramphenicol (Table 1). The antimicrobial activity of a phytochemical has been defined as significant when MIC is below $10 \mu \mathrm{g} / \mathrm{mL}$, moderate when $10 \mu \mathrm{g} / \mathrm{mL}<\mathrm{MIC}<100 \mu \mathrm{g} / \mathrm{mL}$ or low when MIC > $100 \mu \mathrm{g} / \mathrm{mL}$ (Kuete 2010; Kuete and Efferth 2010). In the present study, MIC values below $10 \mu \mathrm{g} / \mathrm{mL}$ were noted with compounds $\mathbf{3 ,} \mathbf{6}$ and $\mathbf{8}$ against several bacterial strains, highlighting their possible use in the control of bacterial infections. The activity of flavonoid 3 was better or equal to that of chloramphenicol in the majority of the bacteria including all tested $K$. pneumoniae, P. stuartii, E. aerogenes, E. cloacae and P. aeruginosa strains (Table 1). This was also the case with compounds $\mathbf{6}$ and $\mathbf{8}$ towards the majority of the tested bacterial strains and mostly the MDR phenotypes. Regarding the involvement of MDR bacteria in treatment failures and the re-emergence of infectious diseases (Blot et al. 2007; Falagas and Bliziotis 2007; Nicolle 2001), the activity of flavonoids 3, 6 and isoflavonoid 8 could be considered very promising. Pseudomonas aeruginosa is an important nosocomial pathogen highly resistant to clinically used antibiotics, causing a wide spectrum of infections and leading to substantial morbidity and mortality

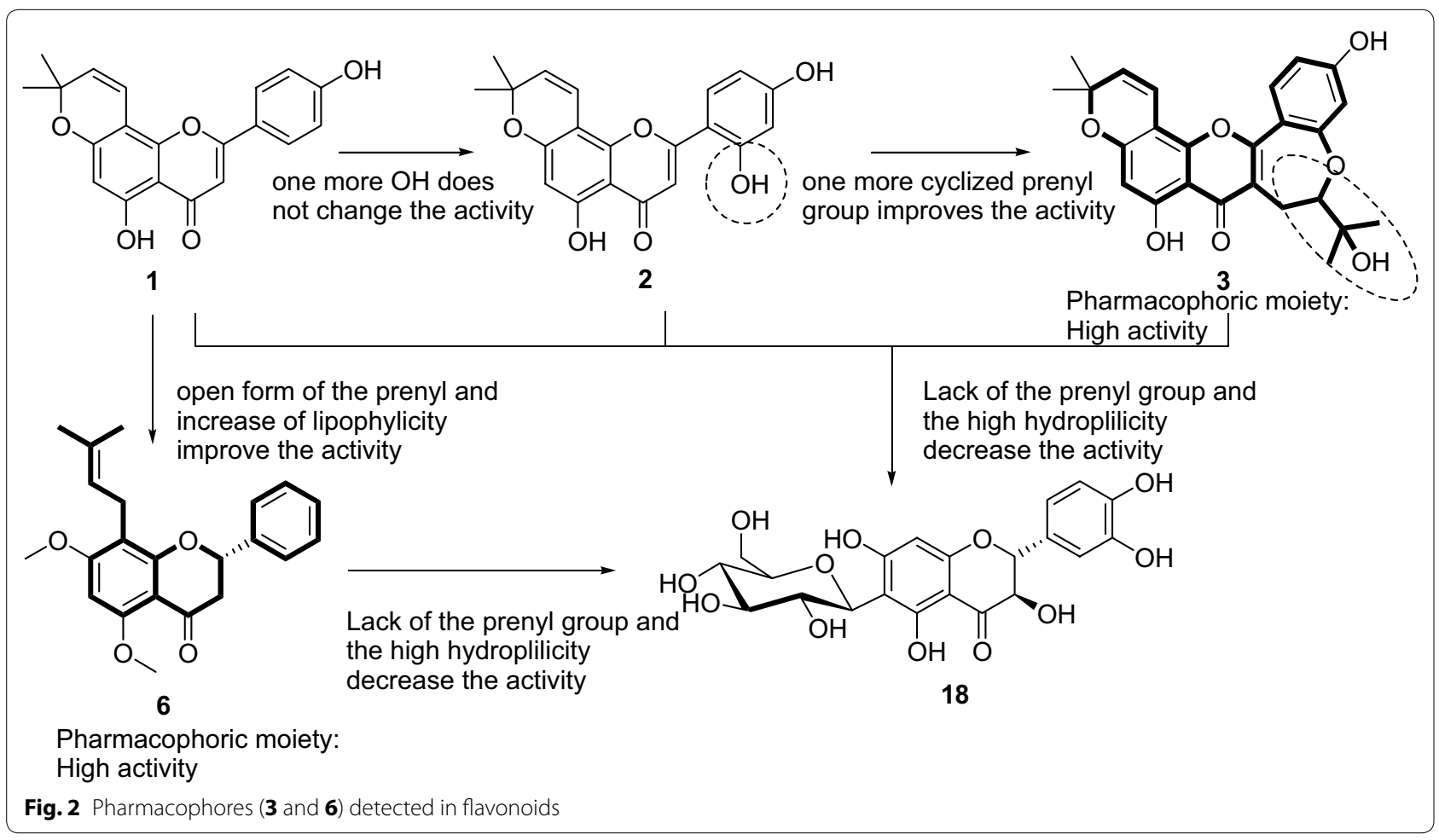


Double cyclisation and loss of the $\alpha, \beta$-unsaturated ketone group decreases the activity,,- -<smiles>[Z]C1Oc2cc3c(cc2C2COc4cc(O)cc(O)c4C1O2)C=CC(C)(C)O3</smiles><smiles>O=c1c(-c2ccc(O)cc2)coc2cc(O)cc(O)c12</smiles>

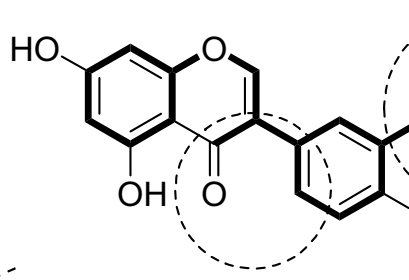

8 Pharmacophoric moiety: High activity

Fig. 3 Representation of pharmacophoric scaffold detected in isoflavonoids

(Cardoso et al. 2007) and was found sensitive to the three compounds $(\mathbf{3}, \mathbf{6}$ and $\mathbf{8})$. MDR Enterobacteriaceae, including K. pneumoniae, E. aerogenes, P. stuartii and $E$. coli, have also been classified as antimicrobial-resistant organisms of concern in healthcare facilities (Nicolle 2001; Tran et al. 2010). The analysis of data of Table 1 shows that MBC/MIC ratios below 4 were recorded with the three best compounds $(3,6$ and 8$)$ in many cases, suggesting that bacterial effects of these phytochemicals could be expected (Mims et al. 1993; Mbaveng et al. 2011, 2012). The data reported herein highlight once more the good pharmacological potential of flavonoids 3, 6 and isoflavonoid 8 and their ability to combat infections involving these bacterial species. Furthermore, the pharmacophoric moiety (8) suggests that hemi-synthesis reaction with neobavaisoflavone could be explored in more details for antibacterial drug development. To the best of our knowledge, the antibacterial activity of the best compounds (3, $\mathbf{6}$ and $\mathbf{8})$ against MDR bacteria is being reported for the first time. However, several flavonoids and isoflavonoids are known to possess antibacterial activities against both drug-sensitive and MDR Gram-negative phenotypes (Kuete et al. 2010, 2011a; Ndhlala et al. 2013; Ngameni et al. 2013).

\section{Methods}

\section{General procedure}

Column chromatography $(\mathrm{CC})$ and thin layer chromatography (TLC) were performed over silica gel $60 \mathrm{H}$ (particle size $90 \%<45 \mathrm{~mm}$ ), 200-300 mesh silica gel silica gel GF254, respectively. 1D- and 2D-NMR spectra were carried out with a Bruker DRX-400 MHz. Melting points were measured by an Electro thermal IA 9000 digital melting point apparatus and are uncorrected.

\section{Plant material}

Plant species were collected in Yaoundé (Centre Region, Cameroon) and in Dschang (West Region, Cameroon) and identified by the specialist of the national herbarium in Yaoundé, Cameroon where their voucher are kept under the registration codes: Teclea afzelii Engl. (Rutaceae) (10674/SRF/Cam), Erythrina excelsa Baker (Fabaceae) (61487/HNC), Erythrina senegalensis A. Rich. (Fabaceae) (59409/HNC), Echinops giganteus A. Rich. (Asteraceae) (23647/SRF-Cam), Pachystela msolo Engl. (Sapotaceae) (3849/SRFK), Garcinia ovalifolia Oliv. (Guttiferae) (55523/HNC) and Alchornea laxiflora (Benth) Pax and Hoff (Euphorbiaceae) (45363HNC). 


\section{Ethics statement}

For the collection of plants, no specific permits were required for the described field studies. For any location/ activity, no specific permissions were required. All locations where the plants were collected were not privatelyowned or protected in any way and the field studies did not involved endangered or protected species.

\section{Extraction and isolation}

Compounds tested in the present work were either previously isolated in our research team $(\mathbf{1 - 1 0 , 1 4 )}$ or newly isolated $(12,13,15-19)$. Compounds $1-3$ were obtained from the roots of Milicia excelsa whilst $\mathbf{4}$ was identified from the leaves as previously reported (Ouete et al. 2013, 2014). Compounds 5 and $\mathbf{6}$ were isolated from Echinops giganteus (Asteraceae) (Kuete et al. 2013), while 7 and 8 were obtained from Erythrina sigmoidea (Fabaceae) (Kuete et al. 2014). Compounds 9 and 10 were isolated from Zanthoxylum buesgenii (Rutaceae) (Sandjo et al. 2014). Compound 14 was isolated from Dorstenia elliptica (Moraceae) (Abegaz et al. 2004).

Compound $\mathbf{1 1}$ in addition to $\mathbf{9}$ and $\mathbf{1 0}$ were isolated from the roots of Teclea afzelii (Rutaceae); Hence, airdried roots $(7 \mathrm{~kg})$ were macerated in $\mathrm{MeOH} / \mathrm{DCM}$ (1:1, $\mathrm{v} / \mathrm{v}$ ) for $48 \mathrm{~h}$ and the organic (286 g) solid obtained after evaporation of the solvents in vacuo was further extracted with hexane (hex, $41 \mathrm{~g}$ ), ethyl acetate (EA, $44 \mathrm{~g}$ ) and $\mathrm{MeOH}$ (201 g). The EA fraction was purified by column chromatography on silica gel in gradient conditions of hex/EA. Three compounds were isolated as follows: 9 (6 mg), $\mathbf{1 0}(5 \mathrm{mg})$ and $\mathbf{1 1}(10 \mathrm{mg})$.

Compound 12 was obtained from the roots of Erythrina excelsa (2.2 kg) (Fabaceae); The crude extract obtained from the maceration of the air-dried roots was fractioned by silica gel flash chromatography using hex/ EA in gradient conditions. The fraction issued from hex/ EA (1:1) was chromatographed using the same condition as above from which 12 (45 mg) was isolated. Similarly, 13 (5 mg) was isolated from the roots of Erythrina senegalensis (Fabaceae) as described for 12. Compound 17 $(5.0 \mathrm{mg})$ was isolated from the roots of Echinops giganteus; the powdered roots of E. giganteus (Asteraceae) was macerated successively in DCM/MeOH $(1: 1, \mathrm{v} / \mathrm{v})$ and $\mathrm{MeOH}$ for $48 \mathrm{~h}$ and $24 \mathrm{~h}$, respectively. The organic solutions were pooled together based on their TLC profile. Eighty-one grams of a red dark crude extract were obtained after evaporation in vacuo. Furthermore, the crude extract was poured onto water and extracted with Hex (A, 10 g), DCM (B, 25 g), EA (C, 30 g), n-butanol (D, $5 \mathrm{~g})$. Fraction $\mathrm{B}$ was purified on silica gel $\mathrm{CC}$ using gradient conditions of Hex/EA and $\mathbf{1 7}$ was obtained from the Hex/EA (3:2, v/v). Similarly, bark powder $(2.8 \mathrm{~kg})$ of Pachystela msolo Engl. (Sapotaceae) was extracted with
$\mathrm{DCM} / \mathrm{MeOH}$ (1:1), yielding a dark crude extract (30 g). The purification of this later in gradient conditions of Hex/EA afforded $15(5 \mathrm{mg})$. The stem bark $(2.5 \mathrm{~kg})$ of Garcinia ovalifolia (Guttiferaceae) was air-dried, ground and macerated in $\mathrm{MeOH}$ for $48 \mathrm{~h}$. A brown residue (120 g) was obtained after concentrating the organic solution. Vacuum liquid chromatography was used for a first fractionation with gradient of hex/EA and $\mathrm{EA} / \mathrm{MeOH}$. Fractions obtained from Hex and Hex/EA (3:1, v/v) were pooled together $(1.22 \mathrm{~g})$ and purified by silica gel CC with gradients of the same mixture of solvents to afford 16 (12 mg). Fractions collected from EA/MeOH (9:1 and 4:1) were also pooled together and purified on silica gel $\mathrm{CC}$ with gradients of $\mathrm{DCM} / \mathrm{MeOH}$ to yield compound 18 (90 mg). The stem bark (1.8 kg) of Alchornea Laxiflora (Euphorbiaceae) was macerated in $\mathrm{MeOH}$. The concentrated methanol crude extract (30 g) was subjected to silica gel flash chromatography using Hex (A), EA (B) and $\mathrm{MeOH}(\mathrm{C})$. Fraction $\mathrm{C}(10 \mathrm{~g})$ was purified by silica gel $\mathrm{CC}$ using the gradient of $\mathrm{DCM} / \mathrm{MeOH}$. Compound 19 (15 mg) was isolated from sub-fractions eluted with $\mathrm{DCM} / \mathrm{MeOH}(95: 5)$.

\section{Antimicrobial assays \\ Chemicals for antimicrobial assay}

Chloramphenicol $\geq 98 \%$ (Sigma-Aldrich, St. Quentin Fallavier, France) was used as reference antibiotics (RA) against Gram-negative bacteria. p-Iodonitrotetrazolium chloride $\geq 97 \%$ (INT, Sigma-Aldrich) was used as microbial growth indicator (Eloff 1998; Mativandlela et al. 2006).

\section{Microbial strains and culture media}

The studied microorganisms included sensitive and resistant strains of $P$. aeruginosa, K. pneumoniae, E. aerogenes, E. cloacae, E. coli, P. stuartii, obtained from the American Type Culture Collection. Their bacterial features were previously reported (Kuete et al. 2011a; Lacmata et al. 2012; Seukep et al. 2013; Touani et al. 2014). Nutrient agar were used for the activation of the tested Gram-negative bacteria (Kuete et al. 2011b).

\section{INT colorimetric assay for MIC and MBC determinations}

The minimal inhibitory concentration (MIC) determinations on the tested bacteria were conducted using rapid $p$-iodonitrotetrazolium chloride (INT) colorimetric assay according to described methods (Eloff 1998) with some modifications (Kuete et al. 2008b, 2009). The test samples and RA were first of all dissolved in DMSO/MuellerHinton Broth (MHB). The final concentration of DMSO was lower than $2.5 \%$ and does not affect the microbial growth (Kuete et al. 2007, 2008a). The solution obtained was then added to Mueller-Hinton Broth, and serially 
diluted two fold (in a 96-wells microplate). One hundred microlitre $(100 \mu \mathrm{L})$ of inoculum $1.5 \times 10^{6} \mathrm{CFU} / \mathrm{mL}$ prepared in appropriate broth was then added (Kuete et al. 2008b, 2009). The plates were covered with a sterile plate sealer, then agitated to mix the contents of the wells using a plate shaker and incubated at $37^{\circ} \mathrm{C}$ for $18 \mathrm{~h}$. The assay was repeated thrice. Wells containing adequate broth, $100 \mu \mathrm{L}$ of inoculum and DMSO to a final concentration of $2.5 \%$ served as negative control. The MIC of samples was detected after $18 \mathrm{~h}$ incubation at $37{ }^{\circ} \mathrm{C}$, following addition $(40 \mu \mathrm{L})$ of $0.2 \mathrm{mg} / \mathrm{mL}$ of INT and incubation at $37{ }^{\circ} \mathrm{C}$ for $30 \mathrm{~min}$. Viable bacteria reduced the yellow dye to a pink. MIC was defined as the sample concentration that prevented the color change of the medium and exhibited complete inhibition of microbial growth (Eloff 1998). The minimal bactericidal concentration (MBC) was determined by adding $50 \mu \mathrm{L}$ aliquots of the preparations, which did not show any growth after incubation during MIC assays, to $150 \mu \mathrm{L}$ of adequate broth. These preparations were incubated at $37^{\circ} \mathrm{C}$ for $48 \mathrm{~h}$. The $\mathrm{MBC}$ was regarded as the lowest concentration of extract, which did not produce a color change after addition of INT as mentioned above (Kuete et al. 2008b, 2009).

\section{Conclusion}

Regarding the medical importance of the studied microorganisms, the results obtained and reported in this study interestingly showed how secondary metabolites are still a strong source of inspiration in drug discovery. Thus, the present data provided evidence that neocyclomorusin (3), candidone (6) and neobavaisoflavone (8) could be potential antimicrobial drugs to fight MDR bacterial infections and could also be used as motifs for developing related antibiotics with strong potency. To explore more the therapeutic values of the studied compounds, a combination with commonly used antibiotics will be further performed. Also, the study of the mechanism of action of the effective compounds will be carried out to better understand their inhibitory effects.

\begin{abstract}
Authors' contributions
AMT, LPS, ST, and VK performed the study; AMT, LPS, ARN, PA, BTN and VK contributed to the isolation and/or identification of compounds. AMK, LPS and VK drafted the manuscript. VK designed the experiments; BTN and VK supervised the work; VK provided the facilities for the study. All authors read and approved the final manuscript.
\end{abstract}

\footnotetext{
Author details

${ }^{1}$ Department of Biochemistry, Faculty of Science, University of Dschang, P.O. Box 67, Dschang, Cameroon. ${ }^{2}$ Department of Pharmaceutical Sciences, CSS, Universitade Federal de Santa Catarina, Florianópolis, SC 88040-900, Brazil. ${ }^{3}$ Department of Organic Chemistry, Faculty of Science, University of Yaoundé I, Yaoundé, Cameroon. ${ }^{4}$ P.O. Box 1499, Bafoussam, Cameroon.
}

\section{Acknowledgements}

Authors are thankful to the Cameroon National Herbarium (Yaounde) for the plant identification.
Authors are also thankful to UMR-MD1 (Mediterranean University, Marseille, France) for providing some clinical bacteria.

\section{Competing interests}

The authors declare that they have no competing interests.

Received: 26 August 2015 Accepted: 20 December 2015

Published online: 30 December 2015

\section{References}

Abegaz BM, Ngadjui BT, Folefoc GN, Fotso S, Ambassa P, Bezabih M, Dongo E, Rise F, Petersen D (2004) Prenylated flavonoids, monoterpenoid furanocoumarins and other constituents from the twigs of Dorstenia elliptica (Moraceae). Phytochemistry 65(2):221-226

Ayafor J, Okogun J (1982) Isolation and identification of three new phenolic furoquinoline alkaloids from Teclea verdoorniana Exell and Mendonça (Rutaceae). J Chem Soc Perkin Trans 1:909-915

Basha G, Yadav S, Srinuvasarao R, Prasanthi S, Ramu T, Mangarao N, Siddaiah $V$ (2013) A mild and efficient protocol to synthesize chromones, isoflavones, and homoisoflavones using the complex. Can J Chem 91:763-768

Bennett R, Hasegawa S (1981) Limonoids of calamondin seeds. Tetrahedron 37:17-24

Blot S, Depuydt P, Vandewoude K, De Bacquer D (2007) Measuring the impact of multidrug resistance in nosocomial infection. Curr Opin Infect Dis 20(4):391-396

Cardoso O, Alves AF, Leitao R (2007) Surveillance of antimicrobial susceptibility of Pseudomonas aeruginosa clinical isolates from a central hospital in Portugal. J Antimicrob Chemother 60(2):452-454

Cho JK, Ryu YB, Curtis-Long MJ, Kim JY, Kim D, Lee S, Lee WS, Park KH (2011) Inhibition and structural reliability of prenylated flavones from the stem bark of Morus Ihou on beta-secretase (BACE-1). Bioorg Med Chem Lett 21(10):2945-2948

Davin-Regli A, Bolla JM, James CE, Lavigne JP, Chevalier J, Garnotel E, Molitor A, Pages JM (2008) Membrane permeability and regulation of drug "influx and efflux" in enterobacterial pathogens. Curr Drug Targets 9(9):750-759

Eloff JN (1998) A sensitive and quick microplate method to determine the minimal inhibitory concentration of plant extracts for bacteria. Planta Med 64(8):711-713

Falagas ME, Bliziotis IA (2007) Pandrug-resistant Gram-negative bacteria: the dawn of the post-antibiotic era? Int J Antimicrob Agents 29(6):630-636

Fankam AG, Kuete V, Voukeng IK, Kuiate JR, Pages JM (2011) Antibacterial activities of selected Cameroonian spices and their synergistic effects with antibiotics against multidrug-resistant phenotypes. BMC Complement Altern Med 11:104

Fischbach MA, Walsh CT (2009) Antibiotics for emerging pathogens. Science 325(5944):1089-1093

Gao X, Wu J, Zou W, Dai Y (2014) Two ellagic acids isolated from roots of Sanguisorba officinalis $\mathrm{L}$. promote hematopoietic progenitor cell proliferation and megakaryocyte differentiation. Molecules 19:5448-5458

http://whqlibdoc.who.int/hq/2001/WHO_CDS_CSR_DRS_2001.7.pdf. Accessed October 2014

Kuete V (2010) Potential of Cameroonian plants and derived products against microbial infections: a review. Planta Med 76(14):1479-1491

Kuete V, Efferth T (2010) Cameroonian medicinal plants: pharmacology and derived natural products. Front Pharmacol 1:123

Kuete V, Wabo GF, Ngameni B, Mbaveng AT, Metuno R, Etoa FX, Ngadjui BT, Beng VP, Meyer JJ, Lall N (2007) Antimicrobial activity of the methanolic extract, fractions and compounds from the stem bark of Irvingia gabonensis (Ixonanthaceae). J Ethnopharmacol 114(1):54-60

Kuete V, Ngameni B, Simo CC, Tankeu RK, Ngadjui BT, Meyer JJ, Lall N, Kuiate JR (2008a) Antimicrobial activity of the crude extracts and compounds from Ficus chlamydocarpa and Ficus cordata (Moraceae). J Ethnopharmacol 120(1):17-24

Kuete V, Wansi JD, Mbaveng AT, Kana Sop MM, Tadjong AT, Beng VP, Etoa FX, Wandji J, Meyer JJM, Lall N (2008b) Antimicrobial activity of the methanolic extract and compounds from Teclea afzelii (Rutaceae). S Afr J Bot 74(4):572-576 
Kuete V, Nana F, Ngameni B, Mbaveng AT, Keumedjio F, Ngadjui BT (2009) Antimicrobial activity of the crude extract, fractions and compounds from stem bark of Ficus ovata (Moraceae). J Ethnopharmacol 124(3):556-561

Kuete V, Ngameni B, Tangmouo JG, Bolla JM, Alibert-Franco S, Ngadjui BT, Pages JM (2010) Efflux pumps are involved in the defense of Gramnegative bacteria against the natural products isobavachalcone and diospyrone. Antimicrob Agents Chemother 54(5):1749-1752

Kuete V, Alibert-Franco S, Eyong KO, Ngameni B, Folefoc GN, Nguemeving JR, Tangmouo JG, Fotso GW, Komguem J, Ouahouo BM, Bolla JM, Chevalier J, Ngadjui BT, Nkengfack AE, Pages JM (2011a) Antibacterial activity of some natural products against bacteria expressing a multidrug-resistant phenotype. Int J Antimicrob Agents 37(2):156-161

Kuete V, Kamga J, Sandjo LP, Ngameni B, Poumale HM, Ambassa P, Ngadjui BT (2011b) Antimicrobial activities of the methanol extract, fractions and compounds from Ficus polita Vahl. (Moraceae). BMC Complement Altern Med 11:6

Kuete V, Sandjo L, Wiench B, Efferth T (2013) Cytotoxicity and modes of action of four Cameroonian dietary spices ethno-medically used to treat Cancers: Echinops giganteus, Xylopia aethiopica, Imperata cylindrica and Piper capense. J Ethnopharmacol 149(1):245-253

Kuete V, Sandjo LP, Djeussi DE, Zeino M, Kwamou GM, Ngadjui B, Efferth T (2014) Cytotoxic flavonoids and isoflavonoids from Erythrina sigmoidea towards multi-factorial drug resistant cancer cells. Invest New Drugs 32:1053-1062

Kuster R, Robson R, Bernardo R, Da Silva A, Parente J, Mors W (1994) Furocoumarins from the rhizomes of Dorstenia brasiliensis. Phytochemistry $36: 221-223$

Lacmata ST, Kuete V, Dzoyem JP, Tankeo SB, Teke GN, Kuiate JR, Pages JM (2012) Antibacterial activities of selected Cameroonian plants and their synergistic effects with antibiotics against bacteria expressing MDR phenotypes. Evid Based Complement Alternat Med 2012:623723

Marti G, Eparvier V, Litaudon M, Grellier P, Guéritte F (2010) A new xanthone from the bark extract of Rheedia acuminata and antiplasmodial activity of its major compounds. Molecules 15:7106-7114

Mativandlela SPN, Lall N, Meyer JJM (2006) Antibacterial, antifungal and antitubercular activity of (the roots of) Pelargonium reniforme (CURT) and Pelargonium sidoides (DC) (Geraniaceae) root extracts. S Afr J Bot 72(2):232-237

Mbaveng AT, Kuete V, Mapunya BM, Beng VP, Nkengfack AE, Meyer JJ, Lall N (2011) Evaluation of four Cameroonian medicinal plants for anticancer antigonorrheal and antireverse transcriptase activities. Environ Toxicol Pharmacol 32(2):162-167

Mbaveng AT, Kuete V, Ngameni B, Beng VP, Ngadjui BT, Meyer JJ, Lall N (2012) Antimicrobial activities of the methanol extract and compounds from the twigs of Dorstenia mannii (Moraceae). BMC Complement Altern Med 12:83

Mims C, Playfair J, Roitt I, Wakelin D, Williams R (1993) Antimicrobials and chemotherapy. In: Mims CA, et al (eds) Med Microbiol Rev, vol. 35, pp $1-34$

Ndhlala AR, Amoo SO, Ncube B, Moyo M, Nair JJ, Van Staden J (2013) 16-antibacterial, antifungal, and antiviral activities of African medicinal plants. In: Kuete V (ed) Medicinal plant research in Africa: Pharmacology and Chemistry. Elsevier, Oxford, pp 621-659

Ngameni B, Fotso GW, Kamga J, Ambassa P, Abdou T, Fankam AG, Voukeng IK, Ngadjui BT, Abegaz BM, Kuete V (2013) 9-Flavonoids and related compounds from the medicinal plants of Africa. In: Kuete $V$ (ed) Medicinal Plant Research in Africa: Pharmacology and Chemistry. Elsevier, Oxford, pp 301-350

Nicolle L (2001) Infection control programmes to contain antimicrobial resistance. World Health Organization, Geneva (WHO/CDS/CSR/DRS/20017)

Nikaido H (2009) Multidrug resistance in bacteria. Annu Rev Biochem 78:119-146
Nkengfack AE, Vouffo TW, Fomum ZT, Meyer M, Bergendorff O, Sterner O (1994) Prenylated isoflavanone from the roots of Erythrina sigmoidea. Phytochemistry 36(4):1047-1051

Nkengfack AE, Vardamides JC, Fomum ZT, Meyer M (1995) Prenylated isoflavanone from Erythrina eriotricha. Phytochemistry 40(6):1803-1808

Noguchi A, Yoshihara T, Ichihara A, Sugihara S, Koshino M, Kojima M, Masaoka Y (1994) Ferric phosphate-dissolving compound, alfafuran, from alfalfa (Medicago sativa L.) in response to iron-deficiency stress. Biosci Biotechnol Biochem 58:2312-2313

Nunes F, Barros-Filho B, de Oliveira M, Andrade-Neto M, de Mattos M, Mafezoli J, Pirani J (2005) ${ }^{1} \mathrm{H}$ and ${ }^{13} \mathrm{C}$ NMR spectra of 3,8-dimethoxyfuro[3,2-g] coumarin and maculine from Esenbeckia grandiflora Martius (Rutaceae). Magn Reson Chem 43:864-866

Ouete JL, Sandjo LP, Kapche DW, Liermann JC, Opatz T, Simo IK, Ngadjui BT (2013) A new flavone from the roots of Milicia excelsa (Moraceae). Z Naturforsch C 68(7-8):259-263

Ouete JL, Sandjo LP, Kapche DW, Yeboah SO, Mapitse R, Abegaz BM, Opatz T, Ngadjui BT (2014) Excelsoside: a new benzylic diglycoside from the leaves of Milicia excelsa. Z Naturforsch C 69(7-8):271-275

Rawat P, Kumar M, Sharan K, Chattopadhyay N, Maurya R (2009) Ulmosides A and B: flavonoid 6-C-glycosides from Ulmus wallichiana, stimulating osteoblast differentiation assessed by alkaline phosphatase. Bioorg Med Chem Lett 19:4684-4687

Rice LB (2006) Unmet medical needs in antibacterial therapy. Biochem Pharmacol 71(7):991-995

Saleem M, Nazir M, Ali MS, Hussain H, Lee YS, Riaz N, Jabbar A (2010) Antimicrobial natural products: an update on future antibiotic drug candidates. Nat Prod Rep 27(2):238-254

Sandjo LP, Kuete V, Tchangna RS, Efferth T, Ngadjui BT (2014) Cytotoxic benzophenanthridine and furoquinoline alkaloids from Zanthoxylum buesgenii (Rutaceae). Chem Cent J 8(1):61

Seukep JA, Fankam AG, Djeussi DE, Voukeng IK, Tankeo SB, Noumdem JA, Kuete AH, Kuete V (2013) Antibacterial activities of the methanol extracts of seven Cameroonian dietary plants against bacteria expressing MDR phenotypes. Springerplus 2:363

Shi J, Zhang X, Jiang H (2010) 2-(penta-1,3-diynyl)-5-(3,4-dihydroxybut-1-ynyl) thiophene, a novel NQO1 inducing agent from Echinops grijsii Hance. Molecules 15:5273-5281

Touani FK, Seukep AJ, Djeussi DE, Fankam AG, Noumedem JA, Kuete V (2014) Antibiotic-potentiation activities of four Cameroonian dietary plants against multidrug-resistant Gram-negative bacteria expressing efflux pumps. BMC Complement Altern Med 14:258

Tran QT, Mahendran KR, Hajjar E, Ceccarelli M, Davin-Regli A, Winterhalter M, Weingart H, Pages JM (2010) Implication of porins in beta-lactam resistance of Providencia stuartii. J Biol Chem 285(42):32273-32281

Wang D, Li F, Jiang Z (2001) Osteoblastic proliferation stimulating activity of Psoralea corylifolia extracts and two of its flavonoids. Planta Med 67:748-749

Wiedemann B, Lerche H, Lotter H, Neszmelyi A, Wagner H, Müller A (1999) Two novel triterpenoids from the stemwood of Herrania cuatrecasana. Phytochemistry 52:333-337

\section{Submit your manuscript to a SpringerOpen ${ }^{\circ}$ journal and benefit from:}

- Convenient online submission

- Rigorous peer review

- Immediate publication on acceptance

- Open access: articles freely available online

- High visibility within the field

- Retaining the copyright to your article

Submit your next manuscript at $>$ springeropen.com 